\title{
PRO DAN KONTRA TENAGA KERJA ASING MASUK KE INDONESIA DI TENGAH PANDEMI COVID-19
}

\author{
Yuwono Prianto ${ }^{1}$, Nabila Annisa Fuzain ${ }^{2}$, Afif Farhan ${ }^{3}$ \\ ${ }^{1}$ Fakultas Hukum, Universitas Tarumangara Jakarta \\ Email : Yuwonop@fh.untar.ac.id \\ ${ }^{2}$ Fakultas Hukum, Universitas Tarumanagara Jakarta \\ Email: nabilannisafuzain@gmail.com \\ ${ }^{3}$ Fakultas Hukum, Universitas Tarumanagara Jakarta \\ Email: afiffarhan3002@gmail.com
}

\begin{abstract}
The news of the arrival of foreign workers to Indonesia is the pros and cons in the midst of the Covid-19 pandemic. This triggers polemics and rejection from the community. Many think that the arrival of foreign workers is an injustice by the government towards local workers, given the high level of unemployment in Indonesia, especially during this pandemic, many local workers have lost their jobs. Actually the arrival of foreign workers is not a threat to local workers because the formulation of foreign workers is only for experts, who are not controlled by local workers. The research method used is normative law, by analyzing legal norms, both law in the sense of statutory regulations and unwritten laws that apply in society. The legal protections provided by the government to local workers through the establishment of certain conditions for foreign workers is seen as still not showing in favor of local workers, thus creating resistance among the community. A policy package is needed that provides a stimulus to national entrepreneurs and UMKM so that they absorb more local workers.
\end{abstract}

Keywords: justice; foreign workers; job creation law.

\begin{abstract}
ABSTRAK
Berita kedatangan TKA ke Indonesia menjadi pro dan kontra ditengah Pandemi Covid-19. Hal ini memicu polemik dan penolakan dari masyarakat. Banyak yang beranggapan kedatangan tenaga kerja asing adalah ketidakadilan pemerintah terhadap pekerja lokal, mengingat masih tingginya tingkat pengangguran di Indonesia apalagi di masa pandemi ini banyak pekerja lokal yang telah kehilangan pekerjaanya. Sebenarnya kedatangan TKA bukanlah ancaman bagi tenaga lokal karena formulasi TKA hanya untuk ahli, yang tidak dikuasai oleh tenaga kerja lokal. Metode penelitian yang digunakan adalah hukum normatif, dengan menganalisis norma hukum, baik hukum dalam artian peraturan perundang-undangan dan hukum tidak tertulis yang berlaku didalam masyarakat. Perlindungan hukum yang diberikan pemerintah terhadap tenaga kerja lokal melalui penetapan syarat tertentu bagi TKA dipandang masih belum menunjukan keberpihakan terhadap tenaga kerja lokal sehingga memunculkan resistansi dikalangan warga masyarakat. Diperlukan paket kebijakan yang memberi stimulus pada pengusaha nasional dan UMKM sehingga lebih banyak menyerap tenaga kerja lokal.
\end{abstract}

Kata kunci: keadilan; tenaga kerja asing; uu cipta kerja.

\section{PENDAHULAN Latar Belakang}

Pandemi Covid-19 memberikan dampak negatif kepada Indonesia baik dari segi sosial maupun ekonomi, banyak pekerja kehilangan pekerjaannya di berbagai bidang profesi. Berdasarkan hasil penelitian Badan Pusat Statistik, tingkat pengangguran bulan Februari 2021 terdapat 8,75 juta orang, atau meningkat 1,82 juta dari Februari 2020. Meskipun meningkat namun lebih baik dari bulan Agustus 2020, dimana jumlah penganggurannya mencapai 9,77 juta. (money kompas.com, 2021) .

Kepala Badan Pusat Statistik, menyatakan bahwa Covid-19 memiliki efek yang buruk untuk 15,71 juta Tenaga kerja Indonesia karena waktu kerja mereka harus dikurangi dan berdampak pada gaji mereka (Suhariyanto, 2021). Data ini menunjukkan bagaimana Covid-19 berdampak buruk bagi pekerja. Sehingga banyak tenaga kerja menjadi pengangguran karena Covid-19. Di 
sisi lain, masyarakat sulit mendapatkan pekerjaan karena lowongan pekerjaan dari industri terbatas.

Di masa Pandemi Covid-19, Pemerintah mengizinkan TKA datang ke Indonesia, padahal pemerintah sendiri sedang menerapkan Pemberlakuan Pembatasan Kegiatan Masyarakat (PPKM) dan ini mengesankan Pemerintah pro kepada perusahaan pengguna TKA. Isu kedatangan TKA ke Indonesia menjadi headline di media massa. Kabar tersebut menimbulkan pro dan kontra ditengah masyarakat, sehingga membuat masyarakat Indonesia geram, khususnya pekerja yang kena PHK, komplain ke pemerintah (KompasTV, 2020).

Menteri Tenaga Kerja mencatat sedikitnya terdapat 92.058 orang tenaga kerja asing didominasi China, Korea Selatan, dan Jepang (databoks.katadata.co.id, 2021). Hal ini menurun dari bulan Mei 2020 jumlah TKA sebanyak 93.374 orang, dan bulan Mei 2019 jumlah TKA sebanyak 95.168 orang (cnbcindonesia.com, 2021). Terlebih banyak TKA tersebut merupakan unskill labour atau buruh kasar dan mereka berasal negara Tiongkok yang dikaitkan dengan kontrak kerja sama sebelumnya (turnkey project bernilai 120 triliyun) antara Pemerintah Indonesia dan Pemerintah Tiongkok. (Nurhidayati, 2019). Kondisi ini menimbulkan ketidakadilan dapat memicu konflik sosial di masyarakat. Pemerintah dinilai tidak peka dengan mengizinkan pihak perusahaan pemberi kerja memakai TKA lebih banyak dibandingkan tenaga lokal.

Masuknya investasi asing dan TKA, disatu sisi berdampak positif meningkatkan investasi, memperluas lapangan pekerjaan, alih teknologi, serta transfer of knowledge untuk pengembangan kapasitas TKI dengan harapan kedepannya Indonesia memiliki TKI yang lebih terampil, sehingga dapat meningkatkan kualitas SDM di dalam negeri yang lebih luas. Namun, kedatangan serta penggunaan TKA bisa menjadi ancaman jika tidak di kontrol. Semestinya, Pemerintah membatasi masuknya TKA melalui penerbitan Beleid, dimana TKI menjadi prioritas utama mendapatkan pekerjaan, sedangkan pengunaan TKA dilakukan sesuai kriteria yang diatur dalam ketentuan UU No. 13 Tahun 2003 tentang Ketenagakerjaan (Rachmad, 2020).

Saat ini, UU No. 11 Tahun 2020 tentang Cipta Kerja dan peraturan pelaksanaannya yaitu PP No. 34 Tahun 2021 tentang Penggunaan Tenaga Kerja Asing mengatur mengenai kewajiban pemberi kerja TKA untuk mengutamakan TKI pada semua jenis jabatan yang tersedia, sepanjang jabatan tersebut belum dapat diduduki oleh TKI serta dengan mempertimbangkan kondisi pasar kerja di dalam negeri. Penggunaan TKA hanya untuk jabatan dan waktu tertentu serta sesuai dengan kompetensi yang ditetapkan lebih lanjut oleh Menteri Ketenagakerjaan setelah mendapat masukan dari menteri teknis (Pasal 33 ayat (1) huruf d UU Cipta Kerja dan Pasal 2 PP No. 34 Tahun 2021).

Regulasi nampaknya telah mengatur dengan baik pembatasan TKA, tetapi implementasinya belum sesuai dengan apa yang tertulis. Pemerintah memiliki peranan penting untuk memberikan perlindungan hukum bagi TKI juga kepastian hukum bagi TKA. Oleh karena itu penting untuk dikaji kembali/review atas peraturan perundang-undangan yang tertulis di bidang ketenagakerjaan dengan implementasinya di lapangan terkait isu ini untuk lebih memberikan keberpihakan, rasa keadilan, mengurangi tingkat pengangguran dan yang lebih meningkatkan kesejahteraan terhadap TKI yang terdampak Pandemi Covid-19 yang hingga saat ini belum berakhir, termasuk di dalamnya review atas kontrak kerja sama Indonesia-Tiongkok di bidang ketenagakerjaan serta usulan rekomendasi berupa paket kebijakan yang menstimulasi penyerapan TKI.

\section{Rumusan Masalah}

Ruang lingkup permasalahan dalam penelitian ini sebagai berikut:

1. Bagaimana pembatasan hukum terhadap TKA selama pandemi Covid-19?

2. Bagaimana proteksi hukum TKI terhadap masuknya TKA ke Indonesia selama pandemi Covid-19? 


\section{Tujuan Penelitian}

Penelitian bertujuan membahas bagaimana:

1. Untuk mengetahui pembatasan hukum terhadap TKA selama pandemi Covid-19.

2. Untuk mengetahui proteksi hukum bagi TKI atas masuknya TKA ke Indonesia selama pandemi Covid-19.

\section{METODE PENELITIAN}

Penelitian ini menggunakan metode penelitian hukum normatif, dengan menganalisis dan membandingkan norma hukum yang tertulis dengan norma hukum yang berlaku di masyarakat (implementasinya) (Soerjono Soekanto dan Sri Mamudji, 2021:13). Penelitian ini fokus pada kajian terhadap data sekunder yang mencakup:

a. Bahan Hukum Primer berupa peraturan perundang-undangan di bidang ketenagakerjaan antara lain: UU No.11 Tahun 2020 Tentang Cipta Kerja, PP No. 34 Tahun 2021 tentang Pengunaan Tenaga Kerja Asing, dan Permenaker No. 8 Tahun 2021 Tentang Pelaksanaan Peraturan Pemerintah Nomor 34 Tahun 2021 serta Permen Hukum dan HAM No.11 Tahun 2020 tentang Larangan Sementara bagi Orang Asing Masuk Wilayah NKRI, Permen Hukum dan HAM No.26 tahun 2020 tentang Visa dan Izin Tinggal di Era New Normal. 27 Tahun 2021 tentang Larangan Orang Asing Masuk Wilayah NKRI Saat Darurat PPKM.

b. Bahan Hukum Sekunder berupa bahan pustaka: buku, artikel, hasil dan data penelitian terkait ketenagakerjaan di Indonesia.

c. Bahan Hukum Tersier berupa Kamus Besar Bahasa Indonesia.

seluruh data tersebut di atas dikumpulkan dan diolah serta dianalisis secara kualitatif untuk mendapatkan pemahaman gejala yang diteliti melalui penggunan logika deduktif dengan menempatkan peraturan perundang-undangan sebagai premis mayor serta fakta-fakta sebagai premis minor.

\section{ANALISIS PEMBAHASAN}

\section{Pembatasan Hukum Terhadap TKA Selama Pandemi Covid-19.}

Pengunaan TKA tidak bisa dihindarkan mengingat dalam bidang tertentu kemampuan SDM Indonesia kerap belum sesuai dengan kualifikasi yang ditetapkan oleh pihak investor, (Widodo, 2018) sementara dibanyak bidang kualitas SDM di Indonesia memiliki kemampuan untuk bersaing dengan TKA dan pada batas-batas tertentu juga banyak dijumpai SDM Indonesia kualitas nya lebih baik di banding TKA. Seiring berkembangnya dunia di bidang investasi serta ketenagakerjaan, personal utamanya pihak Indonesia kerap kali kurang memberikan pengghargaan kepada tenaga kerja lokal Indonesia dan melebih-lebihkan kemampuan TKA. Para TKA yang dipekerjakan tenaga ahli di Indonesia sering kali bukan tenaga ahli di negara asalnya, mereka kadang selevel mandor yang dalam banyak hal kemampuan nya tidak lebih baik TKI. Namun demikian, masuknya investasi asing hampir sering diiringi tenaga kerja kerja asal negara asal investor sebagai bagian dari persyaratan investasi dengan pertimbangan untuk mengawal dana yang di investasikannya. (Nugraha Pranadita dkk, 2020). Dengan demikian permasalahannya adalah terletak pada kemampuan menegosiasikan syarat-syarat perjanjian investasi asing,

Berdasarkan UU No. 11 Tahun 2020 tentang Cipta Kerja dan peraturan pelaksanaannya yaitu PP No. 34 Tahun 2021 tentang Penggunaan Tenaga Kerja Asing:

1) Tujuan pengunaan TKA dimaksudkan untuk pemenuhan akan tenaga kerja terampil serta profesional, mempercepat proses pembangunan nasional, serta transfer of knowledge demi pengembangan kapasitas TKI dan industri nasional. 
2) Pemberi kerja TKA diwajibkan untuk mengutamakan TKI pada semua jenis jabatan yang tersedia, sepanjang jabatan tersebut belum dapat diduduki oleh TKI serta dengan mempertimbangkan kondisi pasar kerja di dalam negeri.

3) Penggunaan TKA hanya untuk jabatan dan waktu tertentu serta sesuai dengan kompetensi yang ditetapkan lebih lanjut oleh Menteri Ketenagakerjaan setelah mendapat masukan dari menteri teknis.

Selain itu, terdapat 3 (tiga) kebijakan yang telah diterbitkan Pemerintah terkait penggunaan atau perizinan TKA di masa pandemi Covid-19 sebagai berikut:

1) Tanggal 31 Maret 2020, Menteri Hukum dan HAM mengeluarkan Permen Hukum dan HAM No. 11 Tahun 2020 tentang Larangan Sementara Bagi Orang Asing Masuk Wilayah NKRI (Republik Indonesia, 2020). Berdasarkan peraturan tersebut pekerja asing dibatasi hanya untuk mengerjakan Proyek Strategis Nasional.

2) Tanggal 29 September tahun 2020, kebijakan di atas di revisi melalui Permen Hukum dan HAM No. 26 Tahun 2020 tentang Visa dan Izin Tinggal di Era New Normal (Republik Indonesia, 2020). Peraturan ini memberikan kelonggaran dimana semua TKA diperbolehkan bekerja di Indonesia setelah memenuhi syarat sehat protokol. Peraturan ini membuat TKA yang datang ke Indonesia lebih mudah dari sebelumnya.

Beberapa video kedatangan TKA menunjukkan bahwa orang menemukan beberapa pekerja asing yang bekerja adalah tenaga kerja tidak terampil. Hal ini bertentangan dengan peraturan pemeritah. Secara kasat mata melalui berbagai macam media masa masyarakat Indonesia menemukan berbagai kasus TKA yang masuk pada masa pandemi, tidak semua yang memiliki keahlian khusus, banyak diantara mereka bekerja pada bidang-bidang yang tidak memerlukan keahlian tinggi.

3) Untuk menanggapi situasi tersebut, Pemerintah pada 19 Juli 2021 mengeluarkan kebijakan ketiga yaitu Permen Hukum dan HAM No. 27 Tahun 2021 tentang Larangan Orang Asing Masuk Wilayah NKRI Saat Darurat PPKM. Peraturan ini pekerja asing dilarang masuk ke Indonesia, kecuali untuk keperluan Diplomatik dan mendukung kesehatan.

Dinamika kebijakan pemerintah terkait masuknya TKA di masa pandemi Covid-19 secara nyata memperlihatkan bahwa pejabat yang terkait belum memahami tentang tujuan fungsi dan tugas negara yang menjadi dasar bagi setiap kebijakan yang dibuat oleh pemerintah di tengarai oleh berbagai pihak bahwa oknum pejabat tertentu menyisipkan kepentingan pribadi didalam kebijakan yang dibuatnya, dengan tidak memperhatikan kepentingan nasional secara luas dalam wujud keberpihakan terhadap tenaga kerja lokal yang pada situsi pandemi banyak mengalami kehilangan pekerjaan akibat perusahaan tempatnya bekerja tidak mampu mengantisipasi berbagai gejolak yang timbul akibat mewabahnya Covid-19 didalam negeri maupun dimanca negara.

Oknum pejabat yang bersangkutan seperti mengalami disorientasi ditengah gelombang wabah Covid-19 dan mengabaikan amanah jabatan seorang pejabat publik yang mengemban misi mengupayakan pencapaian kesejahteraan serta keadilan sosial bagi rakyat Indonesia, sebagaimana pesan moral dalam pembukaan dan batang tubuh UUD 1945. Bagaimanapun orang pejabat publik harus terus meneguhkan komitmen yang dengan lebih mendahulukan kepentingan nasional yang hal ini termanifestasi dalam wujud kepentingan para tenaga kerja lokal.

Permasalahan politik hukum dari TKA adalah mereka banyak yang masuk kategori unskilllabour alias buruh kasar yang tidak punya keterampilan sama sekali. Mereka utamanya berasal dari Tiongkok. Ini disebabkan karena adanya kerja sama turnkey project bernilai 120 triliyun antara Indonesia dan Tiongkok yang mensyaratkan pengerjaan, biaya, termasuk tenaga kerja dari negara investor (Tiongkok). Selain itu, masuknya TKA asal Tiongkok juga karena efek dari adanya keterbukaan investasi, faktor kebijakan bebas visa, serta pemberlakuan masyarakat ekonomi ASEAN. (Nurhidayati, 2019) 
Temuan berbagai pihak mengenai serbuan TKA ke wilayah Indonesia sebagaimana terungkap di Lumajang-Jawa Timur dan Morowali-Sulawesi Tengah serta tempat-tempat lain diberbagi penjuru tanah air memperlihatkan rendahnya komitmen aparatur sipil negara dalam upaya membatasi masuknya tenaga kerja asing di masa pandemi yang sekaligus menunjukan lemahnya sense of crisis pihak-pihak yang diberi amanat untuk menjalankan tugas contoh kedatangan warga negara India yang melarikan diri dari negeri nya saat varian D covid-19 meluas dan mereka secara swadaya menyewa pesawat ke Indonesia dengan dalih wisata. Sekiranya pejabat imigrasi di berbagai bandara di tanah air mempunyai sense of crisis mereka tidak akan mengizinkan pesawat charteran tersebut mendarat di bandara. Kasus lainnya dapat disebut merapatnya kapal persiar Diamond Princess dan Word Dream di pulau Sebaru .

Kelalaian pejabat terkait atas masuknya warga negara asing saat pandemi covi-19 dimana mereka secara potensial mereka memperluas penyebaran Covid-19 ke berbagai penjuru wilayah di Indonesia yang dengan sendirinya secara nyata membahayakan keselamatan dan kelangsungan hidup warga negara indonesia yang didatangi warga negara asing tersebut. Seharusnya sejak awal pemerintah lebih memperketat masuknya TKA ke Indonesia dengan alasan apapun, untuk persoalan investasi kegiatan proyektor terkait kalau perlu dihentikan sementara sampai Indonesia menangani Covid-19 dengan baik. Kalaupun tersebut dilakukan, pandemi Covid-29 bisa dijadikan sebagai dasar/alasan untuk menunda bekerjanya TKA disuatu proyek dan menggantikan mereka dengan tenaga kerja lokal. Semua itu dapat dinegosiasikan dengan pihak investor dan pemerintahan mereka, sepanjang pemerintah indonesia memberikan penjelasan yang rasional tentunya pihak investor dapat menerima alasan tersebut. Bagaimana pun masuknya TKA disamping kecemburuan tenaga kerja yang menganggur/dirumahkan/kehilangan pekerjaan akibat resesi pandemi juga dapat mengurangi risiko meluasnya penularan Covid-19 besar kemungkinan dibawa oleh para TKA tersebut.

\section{Proteksi Hukum TKI Terhadap Masuknya TKA ke Indonesia Selama Pandemi Covid 19.}

Perlindungan dan pemberian kesempatan kerja yang lebih luas kepada TKI di masa Pandemi Covid-19 merupakan isu sentral yang patut menjadi perhatian Pemerintah. Pemerintah harus mampu memberikan keadilan dan kepastian hukum TKI terhadap masuknya TKA, karena hukum merupakan produk kekuasaan, karenanya substansi hukum harus dapat mampu menyeimbangkan polarisasi antara negara, hukumnya, masyarakatnya, dan keadilannya. (Ahmad fadlil, 2015).

Berbagai macam pemberitaan media massa diketahui bahwa kedatangan TKA selama pandemi Covid-29 telah menimbulkan resistansi yang kuat dari warga masyarakat Indonesia khususnya para pencari kerja yang telah menjadi korban PHK sebagai lanjutan dari resensi ekonomi yang ditimbulkan oleh pandemi Covid-19. Walapun dalam skala tertentu Pemerintah telah mencoba pembatasan terhadap TKA dengan memberlakukan syarat tertentu.

Syarat yang telah ditetapkan dipahami oleh masyarakat sebagai persyaratan yang masih memberi ruang besar untuk bekerja di berbagai proyek atau industri. Sementara angkatan bekerja yang menunggu untuk mendapatkan pekerjaan terus bertambah, seiring bertambahnya jumlah lulusan perguruan tinggi atau SLTA ditambah lagi mantan-mantan pekerja yang menjadi korban PHK yang terus bertambah jumlahnya. Akibat banyaknya perusahaan yang menghentikan kegiatan usahanya atau melakukan relokasi industri ke negara lain seperti Vietnam dan sebagainya.

Sebagaimana yang diatur pada UU Cipta Kerja beberapa Pasal mengatur perlindungan terhadap TKI sebagai berikut: pemberi kerja wajib menempatkan lebih banyak TKI dibanding TKA; menunjuk TKI sebagai pendamping TKA; kewajiban memberikan diklat bagi TKI sesuai kualifikasi jabatan yang diduduki oleh TKA.

Ada baiknya Jika pemerintah mengambil beberapa langkah untuk memproteksi TKI sebagai berikut : 
1. Pemerintah membuka data jumlah TKI dan lapangan pekerjaan yang tersedia baik yang dilakukan oleh investor asing maupun proyek-proyek pemerintah (Proyek Strategis Nasional) termasuk juga kesempatan kerja di luar negeri.

2. Berkenaan dengan anggapan adanya keterbatasan keterampilan dan rendahnya penguasaan teknologi, bagaimanapun pemerintah tetap harus tetap mencari solusi dan tetap memberikan proteksi pada tenaga kerja lokal dengan memprioritaskan memberikan kesempatan kerja kepada tenaga kerja lokal daripada TKA mengingat tingginya angka pengangguran dapat memicu gangguan terhadap stabilitas kemanan dan ketertiban di dalam negeri yang akan memakan social cost yang sangat mahal

3. Pemerintah pusat perlu terus mengetatkan pengawasan kedatangan TKA dilapangan atas implementasi UU Cipta Kerja bidang ketenagakerjaan.

PP No. 34 Tahun 2021 mengatur kewajiban pemberi kerja untuk mengutamakan pengunaan TKI. Sepatutnya Pemerintah harus mendahulukan TKI pada proyek-proyek industri yang sedang dibangun atau yang sedang berjalan untuk menghindari terjadinya kerawanan sosial sebagai buntut dari rasa putus asa masyarakat ketika yang bersangkutan terjebak sebagai pengangguran atau terdesak himpitan ekonomi. Bantuan sosial yang diberikan Pemerintah sangat tidak memadai di banding dengan meningkat macam kebutuhan di masa pandemi sehingga warga masyarakat khususnya para pencari kerja maupun para pencari kerja dengan tingkat penghasilan yang terus-menerus turun kemampuan daya belinya merasa mendapatkan perhatian dan diayomi oleh Pemerintah. Adalah lebih bijaksana jika Pemerintah Pusat hingga Pemerintah Desa terus berupaya menciptakan suasana yang kondusif dengan memberikan bermacam kemudahan bagi pelaku usaha nasional agar bisa terus bertahan dan terus berkembang kegiatan usahanya walaupun pada kondisi pandemi Covid-19 sehingga mereka tertarik untuk terus berkontribusi dalam membuka lapangan kerja kepada masyarakat. Adalah lebih bijaksana jika Pemerintah lebih mendahulukan investor dengan jumlah penduduknya tidak besar sehingga peluang lapangan kerja untuk Tenaga Kerja Indonesia bisa lebih besar kontribusinya, hal ini berbanding terbalik jika Pemerintah mengundang investor dengan penduduknya lebih besar seperti China yang bagaimanapun memberikan lapangan pekerja bagi masyarakatnya, di samping itu sektor UMKM perlu terus didorong dan di fasilitasi agar dapat terus tumbuh dan terus berkreasi dalam menjalankan usahanya sehingga mampun menyerap TKI yang melimpah, dengan demikian kebutuhan dasar warga negara Indonesia lebih terpenuhi berbagai daerah dengan konsekuensi berkurangnya dalam kehidupan masyarakat.

Pandemi covid-19 dikuti resesi ekonomi telah menyebabkan banyak perusahaan di Indonesia telah menghentikan kegiatan usahanya sehingga menyebabkan peningkatan jumlah pengangguran, sementara itu kemampuan pemerintah membuka lapangan kerja mengalami banyak kendala perkenaan dengan itu telah diberlakukan UU Cipta Kerja yang membuka ruang luas bagi TKI untuk berani menjadi pelaku usaha mikro kecil dan menengah (UMKM). Banyak kemudahan yang diberikan pemerintah untuk merintis kegiatan usaha mikro kuliner hingga alat kesehatan seperti masker dan sebagainya yang dapat ditekuni untuk memenuhi bermacam kebutuhan hidup.

Adapun ketentuan pasal UU Cipta Kerja yang memberikan kemudahan berusaha diatur dalam Pasal 2 huruf c, Pasal 6, Pasal 7 perizinan berusaha berbasis risiko, Pasal 12 ayat (1) membebaskan usaha mikro dan kecil dari biaya perizinan berusaha, serta Pasal 90 ayat (3) terkait insentif serta kemudahan usaha dari pemerintah daerah.

Permasalahan utamanya adalah tidak semua pencari kerja baik baru lulus pendidikan atau mereka yang menjadi korban PHK memiliki jiwa kewirausahaan yang dituntut berani mengambil risiko dalam menjalan kan kegiatan usahanya baik skala mikro, kecil atau menengah. Situasi pandemi juga membatasi ruang gerak para pelaku usaha mikro, kecil dan menengah. Banyak petugas penertiban di lapangan kerap kali over acting dan melemahkan potensi ekonomi para 
pengusaha mikro dan kecil saat berupaya menegakkan displin pada situasi pandemi sehingga yang timbul adalah lingkaran setan kemiskinan di antara para pelaku usaha mikro dan kecil. Walau pemerintah pusat hingga kecamatan berupaya mengimplementasikan UU Cipta Kerja melalui berbagai macam kemudahan, menggerakkan niat warga masyarakat untuk membangun sikap mental sebagai wirausaha memerlukan waktu yang relatif lama dan kesabaran pada saat pendampingan oleh instansi terkait atau komponen masyarakat yang ditunjuk.

\section{KESIMPULAN DAN SARAN}

Pembatasan TKA selama pandemi Covid-19 telah dilakukan dalam UU Cipta Kerja dengan menetapkan penggunaan TKA hanya untuk jabatan tertentu serta waktu tertentu kompetensi yang telah ditetapkan Kemnaker disertai dengan beberapa peraturan kebijakan dari menteri hukum dan HAM yang dibatasi hanya untuk strategi nasional untuk keperluan diplomatik dan untuk mendukung kesehatan.

Proteksi hukum terhadap TKI selama pandemi. Diberikan dengan menetapkan pemberi kerja wajib menempatkan lebih banyak TKI dibanding TKA; menunjuk TKI sebagai pendamping TKA; kewajiban memberikan diklat bagi TKI sesuai kualifikasi jabatan yang diduduki oleh TKA. Kedatangan TKA di masa pandemi Covid-19 telah menimbulkan resistansi dari masyarakat, bahkan pada skala tertentu telah mengakibatkan terjadinya tindakan destruktif karena syarat yang ditetapkan pemerintah dipandang masih pro TKA. Bagaimanapun situasinya, pemerintah sepatutnya memberlakukan kebijakan-kebijakan untuk kepentingan nasional dengan memberikan stimulus dan berbagi kemudahan berusaha bagi pelaku usaha nasional maupun UMKM yang banyak menyerap tenaga kerja lokal.

Pemerintah telah memberikan perlindungan hukum terhadap tenaga kerja lokal dengan menentukan syarat-syarat tertentu bagi TKA, harmonisasi hubungan antara pemerintah, pengusaha swasta nasional termasuk diantaranya pelaku UMKM, dan tenaga kerja lokal maupun investor asing beserta TKA mesti terus diupayakan dengan tetap mengacu pada tujuan, fungsi dan tugas negara.

\section{Ucapan Terima Kasih}

Bersama ini tim penulis menyampaikan terima kasih kepada keluarga dan rekan serta mata kuliah Pengantar Hukum kelas GZ di Fakultas Hukum Universitas Tarumanagara yang telah mendukung secara penuh sehingga tim penulis dapat menyelesaikan artikel sebelum batas waktu yang telah ditetapkan.

\section{REFERENSI}

Abduh, Rachmad. (2020). Dampak Sosial Tenagakerja Asing (TKA) Di Indonesia. Sosek: Jurnal Sosial dan Ekonomi, 1(1), 25-28.

Annur, Cindy Mutia. (2021, Juli 6) Jumlah Tenaga Kerja Asing di Indonesia Turun Selama Pandemi Covid-19, diakses dari https://databoks.katadata.co.id/datapublish/2021/07/06/jumlah-tenaga-kerja-asing-diindonesia-turun-selama-pandemi-covid-19.

Badan Pusat Statistik, (2021). Keadaan Pekerja di Indonesia Febuari 2021. Jakarta: Badan Pusat Stastistik.

Hanifah, I. (2021). Peluang Tenaga Kerja Asing Untuk Bekerja Di Indonesia Berdasarkan Rancangan Undang-Undang Cipta Kerja. De Lega Lata: Jurnal Ilmu Hukum, 6(1), 168173.

Nurhidayati, (2019). Perizinan TenagaKerja Asing, Kebijakan Implementasinya. Jurnal Sekretaris dan Manajemen, Volume 3. 241-248. 
Nola, Luthvi Febryka. (2021). Pengendalian Tenaga Kerja Asing Pada Masa Pandemi Covid-19. Volume XIII, Nomor. 11.

Undang-Undang Nomor 11 Tahun 2020 Tentang Cipta Kerja. (Lembaran Negara Republik Indonesia Nomor 245, Tambahan Lembaran Negara nomor 6573).

Peraturan Pemerintah Nomor 34 Tahun 2021 Tentang Pengunaan Tenaga Kerja Asing. (Lembaran

Negara Republik Indonesia Nomor 44, Tambahan Lembaran Negara Nomor 6646).

Peraturan Menteri Nomor 8 Tahun 2021 Tentang Pelaksanaan Peraturan Pemerintah Nomor 34 Tahun 2021. (Berita Negara Republik Indonesia Tahun 2020 Nomor 271).

Peraturan Menteri Hukum dan Hak Asasi Manusia Nomor 11 Tahun 2020 Tentang Pelarangan

Sementara Orang Asing Masuk Wilayah Negara Republik Indonesia (Berita Negara Republik Indonesia Tahun 2020 Nomor 305)

Peraturan Menteri Hukum dan Hak Asasi Manusia Peraturan Nomor 26 Tahun 2020 Tentang Visa

Dan Izin Tinggal Dalam Masa Adaptasi Kebiasaan Baru. (Berita Negara Republik Indonesia Tahun 2020 Nomor 1139).

Peraturan Menteri Hukum dan Hak Asasi Manusia Nomor 27 Tahun 2021 Tentang Pembatasan Orang Asing Masuk Ke Wilayah Indonesia Dalam Masa Pemberlakuan Perbatasan Kegiatan Masyarakat. (Berita Negara Republik Indinesia Tahun 2021 Nomor 827).

Pranadita, Nugraha dan dkk. (2020). Problematika penempatan tenaga kerja asing kaitannya dengan disharmonisasi hubungan kerja dan nasionalime pekerja lokal. Jurnal konsep hukum bisnis dan manajemen, volume 7.

KompasTV, (8 Agustus 2020). Alasan Pemerintah Datangkan Tenaga Kerja Asing Asal China.

Diakses dari https://www.youtube.com/watch?v=xkHOfbuRWGI.

KompasTV, (16 Maret 2020). Viral Video Puluhan TKA China Tiba di Bandara. Diakses dari https://www.youtube.com/watch?v=NAJ2vwN7hss.

Shibab, Najwa. (8 Oktober 2020). Bahlil Lahadalia: UU Cipta Kerja Bukan Untuk Tenaga Kerja Asing. Diakses dari https://www.youtube.com/watch?v=_DV0NjmKPcI.

Suryandono, Widodo. (2018). Tenaga Kerja Asing Analisis Politik Hukum. Jakarta: Yayasan Pustaka Obor Indonesia.

Soekanto Soejono dan Mamudji Sri, (2021). Penelitian Hukum Normatif. Depok: PT RajaGrafindo Persada.

Sumadi, Ahmad fadlil. (2015) Hukum dan Keadilan Sosial dalam Persfektif Hukum Ketatanegara.

Jurnal Konstitusi, Volume 12, Nomor 4.

Sandi, Ferry. (2021, Mei 25). Catat Ini Jawaban Menaker Kenapa RI Dibanjir TKA China. Diakses

dari $\quad$ https://www.cnbcindonesia.com/news/20210525102014-4-248137/catat-inijawaban-menaker-kenapa-ri-dibanjiri-tka-china

Ulya, Fika Nurul. (2021, Mei 5). BPS: Akibat Covid-19, Jumlah Penganguran RI Tembus 8,75 Juta. Di akses dari https://money.kompas.com/read/2021/05/05/131541926/bps-akibatcovid-19-jumlah penganggurri-tembus-875-juta?page=all. 